\title{
DECLARAÇÃO DE BARCELONA
}

Entre 23 e 27 de setembro de 2001, realizou-se em Barcelona, o V CONGRESSO MUNDIAL DE MEDICINA PERINATAL. A finalidade do evento foi a de elaborar normas visando à defesa e promoção dos direitos da mulher e do recém-nascido.

No final do evento, os congressistas elaboraram diretivas que vieram a ser denominadas "DECLARAÇÃO DE BARCELONA SOBRE OS DIREITOS DA MÃE E DO RECÉM-NASCIDO".

Estiveram presentes inúmeras sociedades nacionais e internacionais de Medicina Perinatal, Obstetrícia, Pediatria e Neonatologia em colaboração com fundações, associações, institutos, centros e organizações humanitárias de todo mundo, inclusive do Brasil.

O objetivo desta declaração foi de conseguir que no século XXI, o processo reprodutivo humano, em qualquer parte do mundo, fosse obtido, em condições de bem estar físico, mental e social, tanto para a mãe quanto para o filho.

Considerações finais do evento sobre direitos da mãe:

1. A maternidade deve ser de livre eleição

2. Toda mulher tem direito a receber educação e informação sobre saúde reprodutiva, gravidez, parto, lactação e cuidados neonatais;

3. Todas as mulheres têm direito em qualquer país do mundo a que os governos garantam assistência sanitária correta, com eliminação de riscos desnecessários;

4. Toda mulher tem direito a receber informação adequada sobre os procedimentos e avanços tecnológicos, tanto diagnósticos quanto terapêuticos, utilizados durante a gravidez e o parto;

5. Toda mulher tem direito à nutrição adequada durante a gravidez;

6. Toda mulher assalariada tem direito a não ser marginalizada por causa de uma gravidez;

7. Nenhuma mulher sofrerá discriminação, nem será submetida à marginalização social, por causa de uma interrupção voluntária de sua gravidez;

8. O direito à maternidade não pode ser limitado pelos poderes públicos com base em critérios demográficos ou sociais;

9. Toda mulher tem direito e dever de compartilhar as decisões do processo reprodutivo com o companheiro;

10. Toda mulher tem direito a ser informada dos beneficios da lactação materna com início imediatamente após o parto;

11. Toda mulher tem direito a participar do processo de decisão (diagnóstico e/ou terapêutico) que afete tanto a ela como a seu filho;

12. As mulheres que dão à luz em determinada instituição tem direito a decidir sobre a vestimenta (própria e do recém-nascido) destino da placenta e outras práticas culturalmente importantes para cada pessoa;

13. As mulheres grávidas usuárias de drogas, afetadas pela AIDS ou outros problemas médicos ou sociais, tem direito à ajuda em programas específicos;

14. Toda mulher tem direito à sua intimidade, e os profissionais devem respeita-la. Os profissionais de saúde e a sociedade em geral, não devem aceitar a falta de recursos como escusa para o não cumprimento dos direitos de saúde reprodutiva das mulheres. família.

Assim sendo, a mãe tem seu lugar no contexto social como a força fundamental da 